\title{
Coastal Community Response to the Movement of Literacy: a study on literacy culture in Demak pesantren's
}

\author{
Putut Suharso ${ }^{1,2}$, Sarbini Sarbini ${ }^{3}$ \\ ${ }_{1}^{1}$ Postgraduate Program in Cultural Studies, Sebelas Maret University, Ir. Sutami No. 36A street, Surakarta 57126 Indonesia \\ ${ }_{3}^{2}$ Departement of Library Science, Diponegoro University, Prof. H. Soedarto SH Street, Semarang 50275 Indonesia \\ ${ }^{3}$ Communication of Islamic Broadcasting, Faculty of Ushuludin and Da'wah IAIN Surakarta, Pandawa street, Pucangan, \\ Kartasura, Sukoharjo 57168, Indonesia
}

\begin{abstract}
Coastal communities as open societies have historically known the tradition of literacy rather than inland communities. Openness has greatly influenced the teachings of Islam, which later developed into a Coastal Islam. Coastal Islam was born as a consequence of the birth of pesantren along the coast of Java. For pesantren, literacy culture is often interpreted as a routine activity of reading and writing that can not be separated from modern human lifestyle, especially in the world of education (school). In this millennial era, the culture of literacy is declining, along with the rapid use of social media as a new source of information. This study uses a cultural approach that attempts to describe the empirical realities of coastal communities, in the form of social movements, beliefs, social and cultural behaviors related to cultural literacy in pesantren of Demak district. To analyze the event by collecting data through observation, interview, and tracking documentation narrated in the form of qualitative-descriptive with descriptiveinterpretative analysis. The results of research include; first Salafiyah-type pesantren view literacy culture is the same as reading al-Quran and tool books (Arabic) to understand the Qur'an and Sunnah. Both pesantrens of combination type, The culture of literacy understood the effort towards the culture of the Qur'an and Sunnah for the personal stabilization of the literate by equipping other readings for life skills. The three pesantren Ashriyah, literacy culture is understood as the refraction of reading and writing of the Qur'an and other literary readings, which are hierarchically started from the Kyai, Asatidz, senior to junior Santri, with collaborative, programmed, synergistic and continuous.
\end{abstract}

\section{Introduction}

Indonesia is a maritime country that has a coastline of about $81,000 \mathrm{~km}$, including one of the longest beaches in the world. Indonesia also has a diversity of cultures, religions, and beliefs that live on the coast [1] known to coastal communities. Named coastal communities because they live in coastal areas and the source of economic life depends on the utilization of marine and coastal resources. The term coastal appears in the Mataram Era of the 17th century AD, which distinguishes Java in three cultural areas, Negarigung, Mancanegari, and Coastal. Negarigung is the central area of government that is Solo and Yogya. Located in Mancanegari region outside the territory of the capital but still in the royal power. While the Coast is the northern edge of Java island, which stretches from East to West Cengkal Sewu, Surabaya, Gresik, Sedayu, Tuban, Lasem, Juwana, Pati, Kudus, Jepara, Demak, Kendal, Batang, Pekalongan, Wiradesa, Tegal, Brebes until Cirebon. 
Coastal communities, in general, have become part of a pluralistic society, but have a spirit of togetherness. This means that the structure of coastal communities is a combination of urban and rural community characteristics, so as to establish the system and cultural values. Coastal culture is the result of cultural acculturation of each component that forms the structure of coastal communities. His character and attitude tend to be straightforward, spontaneous, words using Ngoko language, his art is relatively rough in the sense of uncomplicated, his religious style tends to be puritanical Islam, and his mobility is quite high, lifestyle tends to be extravagant and likes luxury, and like to show off. In the face or solve the problem tend not to like the convoluted. The style of social life tends to be egalitarian. They are more respectful of informal leaders such as Kyai than government officials. Such tendencies are influenced by;

(1) their dwelling environment in a plain or transparent coastal area, unlike the mountainous environment; (2) the Islamic style that emphasizes the "overwhelming".

* Corresponding author: putut.suharso@gmail.com 
This egalitarian stance shapes the Islamic coastline often identified as more purist (pure) Islam than the inland Islam that tends to be syncretic. The Islamic style can be seen as the reality of any social entity that describes the phenomenon, that Islam is in the hands of the people experiencing humanization in accordance with its ability to interpret Islam [2]. Interpreting the teachings of Islam greatly influenced the culture of literacy of its adherents. According to Abid al-Jabiri, Islamic tradition is a text tradition; there is no teaching in Islam unless there is a proposition contained in the text of the Qur'an, as well as al-Hadith as the main source of Islam. The emergence of various books of Islamic law from the imams of the madhhab like Imam Hanafi, Imam Maliki, Imam Syafii and Imam Hambali, born from the culture and tradition of literacy in the early Islamic period ie the companions, Tabiin and Tabiit Tabiin very usefully for Muslims until now.

Tradition and culture of literacy pioneered in the period of Tabiin to Muttaqodimin Tabiin inherited by his followers to Indonesia [3] with the emergence of the writings of Muslim poets in Indonesia such as Imam Nawawi al-Bantani which is famous for the book of al-Munir fi Maalimi al-Tanzil, Kiai Bisri Mustofa with his Tafseer, al-lbriz li Ma'rifah Tafsir al-Qur'an al-Aziz, Kiai Saleh Darat with Majmu'at al-Shariat al-Kafiyat lil Awam and a number of Mufassir in Indonesia today. The culture of literacy among pesantren was born because of cultural, social, political and struggle of thinking problems [4]. The literacy of pesantren is not just a literary tradition that forms discourse, but also idealization, obsession, and historical characteristics.

Pesantren holds the spirit of literacy rooted in the education of pesantren which emphasizes humanization. That is, pesantren prioritizes the teaching of moral ethics [2], and runs the learning function without a narrow paradigm. Hence, unwittingly, literacy has taken root in education in pesantren, although the main literature only deals with religious matters. But in the development of cultural literacy shifted from religious texts to texts with socio-economic themes especially related to life skills. People reading the Qur'an, books like Jurumiyah, Alfiah, Safinah, Fiqih Sunnah are not viewed as a culture of literacy. Cultural literacy is interpreted when reading books that come from library books. In Kabupaten Demak the shift of literacy theme occurred when declared Demak as Literacy District on 29 September 2016 by Demak Regent, HM Natsir together with Kemendikbud, USAID Prioritas, Head of SKPD, and education stakeholders and Demak community in Pendopo of Demak Regency as follow up of Movement Literacy in the form of Literacy Movement (Gerakan Literasi Sekolah).

Demak regency is determined to make the district love to read and write and make reading as an obligation and need. The determination was manifested in the form of a Bupati Instruction Letter requiring every day at 09.00am, all schools and pesantren to stop learning time for a moment to read 10 minutes as a marker of support and commitment to creating a literal Demak district.

The directive aims to facilitate all levels of society, students and parents to jointly make "literacy" as a 
culture and tradition. This policy as a follow-up "Let's Review (Ayo Mengaji)" previously existed. The last year of facilitation conducted by establishing a reading park in the urban forest, a corner read every SKPD, smart house, Library and book grants to the pesantren. The books donated to pesantren are not all religious books but books with skills and life skills.

From the description above, this study aims to trace the response of Pesantren in Guntur District of Demak Regency to the culture of literacy in response to the Literacy Movement among pesantren.

\section{Literature review}

The advancement of a nation is not only built with abundant natural wealth, as well as the establishment of established state governance but begins with the existence of the library's role in society through the book civilization [5] or the continuous mastery of literacy from one generation to the next [6]. However, what is happening now, the culture of literacy has been increasingly abandoned by the younger generation, along with the development of knowledge and technology, especially in the digital field. Community activities, especially young people, use the Internet as a means of entertainment.

In fact, literacy-based culture education, including digital literacy, is one of the important aspects that must be applied in educational institutions to foster their deepest interests and talents $[7,8]$. Nevertheless, high literacy mastery must not ignore the socio-cultural aspect, because literacy is part of human culture or culture. The growth of pesantren education culture is based on the strengthening of writing culture. In some academic studies of literary, it is always illustrated that reading habits correlate significantly with writing habits/skills. From reading intellectual works, including various yellow books, acquired a lot of knowledge that can be pondered, discussed, reflected, processed and finally poured in writing.

UNESCO (The United Nations Educational, Scientific and Cultural Organization) states that literacy is more than just literacy. But more than that, literacy is the ability of the individual to use all the potential and skill possessed in his life [9], with understanding that literacy includes the ability to read the word and read the world. According to UNESCO people's understanding of the meaning of literacy is strongly influenced by academic research, institutions, national context, cultural values, as well as experience. The most common understanding of literacy is a set of real skills-especially the cognitive skills of reading and writing-irrespective of the context in which the skill was acquired and from whom it was acquired. UNESCO explains that literacy skills are the right of everyone and are the basis for lifelong learning [10]. Literacy skills can empower and improve the quality of individuals, families, and communities. Due to its multiplier effects, it can help to eradicate poverty, reduce child mortality, population growth, and ensure sustainable development, and the realization of peace. Illiteracy, however, is an 
obstacle to a better quality of life. Reading makes human beings full, conferences make human beings ready, and writing makes people certain [11]. One of the certainties is that he will benefit himself and others.

If we explore in the tradition of literature pesantren culture is very thick compared to general education in Indonesia. Pesantren realized that the first revelation that Allah revealed to Prophet Muhammad SAW contains the word lqra (read!) and also the word Qalam (tool for disseminating in writing about what has been read)? (al-'Alaq: 1-5). Even the words 'ilm and 'aql each are not less than 450 and 49 times mentioned in the Qur'an. It also indicates the importance of science and critical thinking in human life, which assumes the task of the Caliphate on earth.

\section{Research methods}

This study used a qualitative descriptive approach that aims to explain how the pesantren response to the literacy movement in building a culture of literacy. Descriptive qualitative approach used to describe social phenomena occurring in the society $[12,13]$. Then the data obtained by observation, interview and study dusentasi. From the collected data is selected to be primary data in the form of pesantren activity as the perpetrators of literacy and secondary data from the government as policymakers, literature review and other documents relating to the movement of literacy and culture literacy.

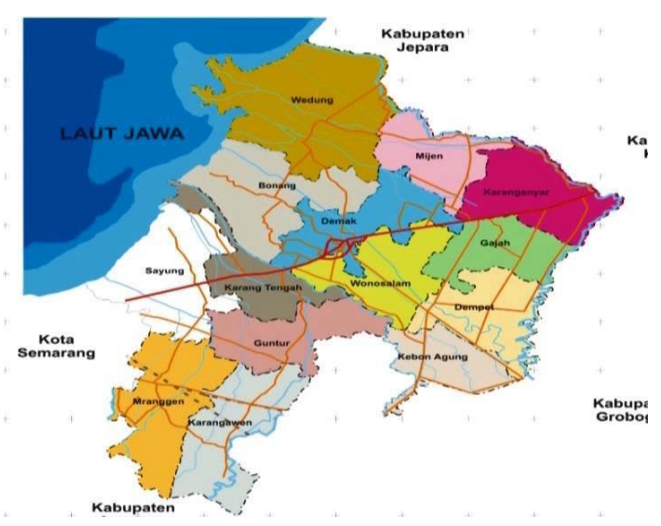

Fig. 1. Research location in Demak district

The research procedure to obtain the data was conducted in-depth interviews with some informants in pesantren in Guntur-Demak sub-district (Fig. 1.) supported by field observation results and juxtaposed with previous research results. Then the results are analyzed through three stages of data reduction, data presentation and conclusion or verification. Methods of data analysis using descriptive qualitative interpretative [14], in the form of interpretation of data through the identification of meaning, categorization, and preparation of structures to disconstruction desired. From the process then report writing. 


\section{Result and discussion}

\subsection{Characteristics of pesantren in Guntur, Demak district}

Ten pesantren in Guntur has different characteristics in the implementation of educational systems as well as in educational materials (Table 1).

Table 1. Characteristics of pesantren

\begin{tabular}{|l|l|l|c|l|}
\hline No & \multicolumn{1}{|c|}{$\begin{array}{c}\text { Name of } \\
\text { Pesantrean }\end{array}$} & Address & $\begin{array}{l}\text { Number } \\
\text { of santri }\end{array}$ & Characteristics \\
\hline 1 & $\begin{array}{l}\text { PP. Al } \\
\text { 'Arifiyyah }\end{array}$ & Wonorejo & 233 & Ashriyah \\
\hline 2 & $\begin{array}{l}\text { PP. Al } \\
\text { Karimah }\end{array}$ & Temuroso & 49 & Ashriyah \\
\hline 3 & PP. Assa'adah & Genteng & 35 & Salafiyah \\
\hline 4 & $\begin{array}{l}\text { PP. Baitut } \\
\text { Tholibin }\end{array}$ & Puritan & 60 & Salafiyah \\
\hline 5 & $\begin{array}{l}\text { PP. Bustanut } \\
\text { Tholibin }\end{array}$ & Bogorejo & 29 & Special \\
\hline 6 & $\begin{array}{l}\text { PP. Darun } \\
\text { Naja }\end{array}$ & Guntur & 50 & Special \\
\hline 7 & $\begin{array}{l}\text { PP. Sabilul } \\
\text { Muttaqin }\end{array}$ & Trimulyo & 507 & Ashriyah \\
\hline 8 & $\begin{array}{l}\text { PP. Tanwirul } \\
\text { Wafa }\end{array}$ & Gaji & 110 & Salafiyah \\
\hline 9 & $\begin{array}{l}\text { PP. Zahrotul } \\
\text { Qur'an }\end{array}$ & Bogosari & 63 & Special \\
\hline 10 & $\begin{array}{l}\text { PP. Putri Al } \\
\text { Asnawiyyah }\end{array}$ & $\begin{array}{l}\text { Sindon } \\
\text { Trimulyo }\end{array}$ & 63 & Special \\
\hline
\end{tabular}

Source: Processed data, 2018

There are 3 types of pesantren; First pesantren Salafiyah, namely the implementation of education in pesantren using the method of Sorogan, Bandongan, and Wetonan. Sorogan is a process of learning that is individual and every student gets the opportunity to learn directly from Kyai or Kyai aide, because Santri required patience, craft, obedience and self-discipline in studying. Bringing themselves to the Sorogan level becomes a pre-requisite to follow the next learning system at the pesantren. While the system of Bandongan (Wetonan) is the learning system of a group of students listening to a teacher/ Kyai who read, translate, and explain the Islamic books in Arabic in the direction and guidance of Kyai consisting of 5 to 500 people Santri. The halaqah is almost the same as the vibe of listening to a teacher or Kyai who read, translate, explain, and review the books in Arabic and Santri each pay attention to his own book and make notes that are considered difficult or important. If kyais are unable to teach in this system, Kyai usually appoints senior Santri to represent him. This method is given to train and test the mental maturity of Santri, so that later become a strong person in religion [15].

Second, pesantren Ashriyah (Khalaf/modern) is the education system and educational materials and curriculum boarding school using modern management system. Kyai no longer takes care of pesantren finances but is left entirely to the pesantren treasurer. The existing curriculum gives with modern curriculum pattern and classical learning system. Here is the difference that Ashriyah pesantren use administration system, 
management, and governance of institution more open than salaf boarding system that is management system, and finance of pesantren always in control of Kyai authority. In the development of pesantren many changes or modifications between Salafiyah with Ashriyah, because Kyai thought and education that develops in facing the development of science and technology while maintaining the basic goals of pesantren education, in spreading and maintaining Islam. In addition, many scholars who have expertise in accordance with the necessary needs. The change of this system that makes pesantren up to now still survive in the middle of society, although there are other factors that make the survive of his pesantren, such as; (2) the tradition of pesantren is not elitist as a valuable capital for the development of humanist education pesantren, (3) the power of pesantren as a bastion of culture and religion for the younger generation, and (4) have strong bonds and intimacy with the surrounding community.

Third, special pesantren, namely education system, and educational materials are special. The Santri at the pesantren only read and memorized the Qur'an, or often called the Tanfidzul hut of the Qur'an. The highest level of education Diniyah this never deserted enthusiast. The concept of pesantren is designed as a place for students of the Qur'an memorizing. This is what makes pesantren have a reputation and prestige for the Santri so instilled pride. Most Pesantrens are managed with financial simplicity. The Santri mostly also come from poor families. Pesantren are reluctant to receive supervision from the government because they do not want the curriculum changed. They believe the curriculum and teaching methods that apply are the best. According to the holder of this pesantren policy, it is deliberate that the Santri not demanded many diplomas.

\subsection{Culture of pesantren literacy in national literacy movement}

Demak community as coastal community has its own characteristics compared to other coastal communities, open communication style, moderate Islamic character on the one hand but on the other hand tend to be Puritan. Even economically have the highest level of poverty in district around, like Jepara, Kudus, Pati and Semarang city.

\subsubsection{School literacy policy}

Demak as Literacy Regency has been declared since 29 September 2016. The Regent of Demak carries out the declaration. Declaration as District Literacy is intended as a first step to build a literate society Demak literate both in reading and writing. Literacy of a movement, to build, implement the culture of reading and writing as well as maintaining the consistency of its programs. Literacy also means practices and social relationships related to knowledge, language, and culture.

The issuance of Regent's Regulation or other supporting regulations to guarantee and strengthen Demak as Literacy Regency. The commitment of the 
Literacy movement is the main factor to encourage and increase the reading interest of the community. Therefore, the above regulation aims to encourage people to make literacy as a culture. Then the provision of adequate reading facilities is an important factor in growing interest in reading. Reading means meant here is reading material, which includes books, magazines, newspapers, and others. However, the fulfillment of the means of reading should be balanced with the availability of librarians who are qualified in the field. This can be accomplished by recruitment of librarians as well as providing technical guidance on library management.

Stakeholder involve in inclusion of Literacy movement of regional leaders (Head and Village Head) and Head of SKPD. As is the policy of the Bupati, the Sub-district Heads to participate in supporting the literacy program by inviting all village heads to revive the village libraries and budgeting village fees to purchase books. village budgets specifically allocated to purchase books or other reading materials. The establishment of a village library and books of collections sufficient to foster a culture of literacy for the general public to obtain the information it wants.

Policies concerning schools where students get character habituation and character development. The availability of school libraries is important in supporting the literacy movement [16]. The library in the school works well in facilitating the students to a literate society (having literacy culture). To support that school must have creative and innovative programs so that children feel the need and necessary with the presence of the library. As the Regent hopes that the school can be as creative as possible it is to compose a reading culture program and provide a list of high quality reading books to students.

\subsubsection{Pesantren response}

Movement of literacy in the context of this research is understood as the ability to access, understand, and use something intelligently through various activities, such as reading, seeing, listening, writing, and/or speaking. Departing from this concept of literacy declared in Demak Regency in response by pesantren in very varied.

(a) Salafiyah Pesantren, understanding the literacy of schools as an activity for reading, writing and listening, using oral language, as well as written language. Understanding based on the Kyai when following the program of literacy movement in the square Demak and various activities organized by the government of Demak District, which in the literature is often called Early Literacy. (b) Modern Pesantren, provides an understanding that literacy of reading and writing activities through the use of libraries, which is oriented to the development of science and technology. Literacy is always associated with an activity in the library. When only reading the books of pesantren matter has not been named as a culture of literacy. In theory, this is called the Dewey Decimal Classification system as a classification of knowledge that makes it easy to use libraries. (c) Special pesantren provides an understanding that literacy 
is the ability to listen, speak, read, write, and count, and describes information based on personal understanding and conclusions. In theory, the term is called Basic Literacy.

Of the three responses are based on the tendency of Kyai and Santri submitted based on the results of interviews and observations in the field. Because of the involvement of Kyai and Santri in the Literacy Movement is very minimal even though the Kyai have received a circle from the Government of Demak Kabutan in the form of Habituation. The reading interest growth through the activities 15 minutes to read (Permendikbud No. 23 of 2015). The purpose of literacy activities at the stage of habituation, increase the love of reading outside the hours of study, improving the ability to understand reading, improve self-confidence as a good reader, cultivate the use of various sources of reading.

\subsection{Culture of pesantren literacy}

Technological developments and information virtualization have caused some pesantren to experience cultural shocks so that among them some forget their identity as a literary house. In the history, pesantren was the forerunner of literary culture that exists in Indonesia. It can be seen that the tradition of Islamic tradition is a text tradition. There is no doctrine in Islam unless there is a proposition contained in the text of the Qur'an, Hadith and the arguments introduced from the two main sources of Islam. The emergence of various books of Islamic law from the Imams of the madhhab such as Imam Hanafi Madzab, Imam Maliki, Imam Syafii and Imam Hambali, teaches us all that the tradition of literacy in early Islam ie the companions, Tabiin, and Tabiit Tabiin very useful for Muslims until now this.

The traditions of the Tabiin Tabiins and their followers to Indonesia can be seen in the writings of Indonesian scholars such as Imam Nawawi al-Bantani who is famous for his Miriki Labid (al-Munir fi Maalimi al-Tanzil) tafsir, Kyai Bisri Mustofa with his Tafsir , al-Ibriz li Ma'rifah Tafsir al-Qur'an al-Aziz, Kyai Saleh Darat with Majmu'at alShariat al-Kafiyat lil Awam and a number of Mufassir in Indonesia today. Not many know who actually Kyai Saleh Darat, Kyai Bisri Mustofa (grandfather Gus Mus) with a variety of monumental works because the tradition of literacy among pesantren has not been maximized. Not many pesantren appreciate the writings of the Ulama because it is a tradition that many develop not a tradition of reading and writing. However, a lot of interest by the Indonesian Muslim community is the tradition of listening (Mustami).

Literacy is born from a number of problems around it; cultural, social, political, and thought-provoking problems. Literacy is not just a discourse, but also an idealization, an obsession, and a historical setting [17]. Pesantren that have libraries in the coastal areas already exist in one institution, but there are special institutions such as coastal libraries [18]. The library has an important role in the program developing this literacy 
Movement [19]. Making pesantren a literacy home that holds a deep-rooted cultural spirit. Education in pesantren based on humanization prioritizes moral ethics teaching and performs didactic functions without narrow adagium. Therefore, without realizing it, literacy is 'directed' in education in pesantren.

The pesantren community has known literature through the literature of the books of the Ulama's work; to know literature through nadham-nadham: Al-Fiyah Ibn Malik, Imrithi or Shorof Science, even recognizing literature through Barzanji's poetry or praises that were echoed after the call to prayer in congregation.

In the literature of pesantren in Indonesia, literature is not only a vehicle for character formation but also plays an important role in the movement of 'new awareness' about Indonesian entity and nation. That was effective because the education in pesantren supports the continuity of its role. Worryingly, in its development, pesantren began to lose its cultural spirit. The pesantren began to experience the emptiness of the elementary figures that guard the identity of an institution called pesantren. Generation of pesantren began to glance at the rides that are considered more promising. The impact of pesantren began to be perceived by the scarcity of the leading figures in the field of religion which also gave birth to monumental works. No more figures of the caliber of Sheikh Nawawi Al-Bantani or the level of Hadratus Shaykh KH. Hasyim Ash'ari.

\section{Conclusions}

Pesantren is the oldest educational institution in Indonesia. In the history of pesantren has a considerable share in developing the culture of literacy in Indonesia, especially in the era before independence. But in the post-independence development, the role in developing the literacy culture is slowing in comparison with other educational institutions. Pesantren was encouraged literacy movement to change the educational system in Indonesia. One that is expected in change is through a cultural change of literacy.

The culture of community literacy has a correlation to the quality of a nation. The habit of reading, writing someone will greatly affect the insight, mental, and behavior of a person. Habits can be nurtured and developed. Therefore, one of the quality improvements of human resources is determined by culture of literacy. Literacy is concerned with the ability to identify, define, discover, evaluate, create efficiencies and organize, use, and communicate information to address various issues. It will nurture the character of learners through the culture of the pesantren literary ecosystem to become lifelong learners. The National Literacy Movement Program is implemented in stages by considering the readiness of pesantren throughout Indonesia. This readiness includes capacity readiness, preparedness of pesantren stakeholders, and readiness of other support systems. 


\section{References}

1 Woodward M 2011 Java, Indonesia and Islam (New York: Springer)

2 Ahmad I 2011 Democracy and Islam Philos. Soc. Crit. 37 459-70

3 Pohl F 2006 Islamic Education and Civil Society: Reflections on the Pesantren Tradition in Contemporary Indonesia Comp. Educ. Rev. 50 389-409

4 Dariah A R, Salleh M S and Shafiai H M 2016 A New Approach for Sustainable Development Goals in Islamic Perspective Procedia - Soc. Behav. Sci. 219 159-66

5 Bradely F 2012 How libraries contribute to sustainable development \& the SDGs IFLA ALP Build. Better Libr. Communities 40

6 Kress G 2003 Literacy in the New Media Age (New York: Routledge)

7 Marsh J and Millard E 2000 Literacy and Popular Culture: Using Children's Culture in the Classroom (London: Sage Publication)

8 Horning A S 2007 Defining Literacy and Illiteracy Read. Matrix 7 69-84

9 UNESCO 2006 Literacy: The Core of Education for All Educ. All Glob. Monit. Rep. 27-35

10 K.G Saur 2001 The Public Library Service: IFLA/UNESCO Guidelines for Development ed C Henry (München: IFLA publications)

11 Guha M and Seale L 2015 Reading maketh a full man J. Ment. Heal. 24 257-60

12 Patton M Q 2015 Qualitative Research \& Evaluation Methods: Integrating Theory and Practice (California: SAGE Publications)

13 Connaway L S and Radford M L 2017 Research Methods in Library and Information Science, 6th Edition (California: Libraries Unlimited)

14 Richey R C and Klein J D 2007 Design and Development Research: Methods, Strategies, and Issues (New Jersey: RoutledgeFalmer)

15 Dhofier Z 1994 Tradisi Pesantren: Studi tentang Pandangan Hidup Kyai (The Tradition of Pesantren: The Study of the Kyai Life View) (Jakarta: LP3ES)

16 Tierney R J and Rogers T 1986 Functional Literacy in School Settings Theory Pract. 25 124-7

17 Hassan A, Suhid A, Abiddin N Z, Ismail H and Hussin H 2010 The role of Islamic philosophy of education in aspiring holistic learning Procedia - Soc. Behav. Sci. 5 2113-8

18 Suharso P, Sudardi B, Widodo S T and Habsari S K 2018 Library Development Strategy for The Community at Coastal Areas IOP Conf. Ser. Earth Environ. Sci. 11612002

19 Naibaho K 2007 Menciptakan Generasi Literat Melalui Perpustakaan (Creating Literate Generation Through Library) Visi Pustaka 9 1-8 